\title{
OPEN Author Correction: 20 Years of DIEAP Flap Breast Reconstruction: A Big Data Analysis
}

\section{Bernard Depypere, Sofie Herregods, Jacob Denolf, Louis-Philippe Kerkhove, Laurent Mainil, Tom Vyncke 10 , Phillip Blondeel \& Herman Depypere}

Correction to: Scientific Reports https://doi.org/10.1038/s41598-019-49125-w, published online 09 September 2019

The original version of this Article omitted an affiliation for Louis-Philippe Kerkhove. The correct affiliations for Louis-Philippe Kerkhove are listed below:

Crunch Analytics, Rodelijvekensstraat 28 bus 002, Gent, Belgium

Faculty of Economics and Business Administration, Gent University, Tweekerkenstraat 2, Gent 9000, Belgium

This has now been corrected in the HTML and PDF versions of this Article.

\begin{abstract}
(c) (i) Open Access This article is licensed under a Creative Commons Attribution 4.0 International License, which permits use, sharing, adaptation, distribution and reproduction in any medium or format, as long as you give appropriate credit to the original author(s) and the source, provide a link to the Creative Commons license, and indicate if changes were made. The images or other third party material in this article are included in the article's Creative Commons license, unless indicated otherwise in a credit line to the material. If material is not included in the article's Creative Commons license and your intended use is not permitted by statutory regulation or exceeds the permitted use, you will need to obtain permission directly from the copyright holder. To view a copy of this license, visit http://creativecommons.org/licenses/by/4.0/.
\end{abstract}

(C) The Author(s) 2020 